\title{
HUBUNGAN JUMLAH KUNJUNGAN ANC DAN STIGMATISASI DENGAN KEIKUTSERTAAN IBU HAMIL DALAM TES HIV SETELAH KONSELING OLEH PETUGAS KESEHATAN (Di Wilayah Kerja Puskesmas Turi Lamongan)
}

\author{
Ponco Indah Arista Sari ${ }^{1}$, Agus Sulistyono ${ }^{2}$, Hari Basuki Notobroto ${ }^{3}$ \\ ${ }^{1}$ Magister Ilmu Kesehatan Masyarakat, Fakultas Kesehatan Masyarakat, Universitas Airlangga, Surabaya \\ ${ }^{2}$ Departemen Obstetri dan Ginekologi RSU Dr. Soetomo Surabaya \\ ${ }^{3}$ Departemen Biostatistik dan Ilmu Kependudukan, Fakultas Kesehatan Masyarakat Universitas Airlangga, \\ Surabaya \\ Alamat Korespondensi: \\ Ponco Indah Arista Sari \\ Email:pindaharistaszulianto@gmail.com
}

\begin{abstract}
HIV AIDS is considered as global threat due to the adverse impacts it brings to all sectors. The number of person with HIV-AIDS increases both in men and women. For pregnant women, HIV is not just a threat to the mother but also for the infant, therefore as to prevent the transmission and complication during pregnancy, screening should be made through an HIV test. The purpose of this study was to analyze the relationship between the number of antenatal care and stigmatization on participation of pregnant women for HIV testing after counseling by Health Workers in the working area of Turi Public Health Center, Lamongan. This study applied cross sectional study. The population in this study consisted of 80 pregnant women. Simple random sampling was chosen for Sampling Technique and it was obtained as many as 42 respondents. Data collection was done using a questionnaire and interviews. Data were analyzed using frequency distribution tables and chi square test with significance level of 5\% $(p=0.05)$. The results revealed that from as many as 42 pregnant women who made antenatal visit $>4$ times, $100 \%$ of these pregnant women did not take HIV test while pregnant women who made only 2-4 times antenatal visit was as many as 16 individuals (64\%) took the test, and only one pregnant woman who took the test on the first visit. Pregnant women who did not have the stigmatization, $100 \%$ took the $H I V$ test. Statistical analysis showed no correlation between the number of antenatal visits $(p=0.000)$ and stigmastization $(p=0.000)$ of pregnant women for HIV testing after counseling by Health Workers. It is necessary to increase the provision of information and education for the pregnant women through health promotion concerning the importance of HIV testing and antenatal visits to the Health Care.
\end{abstract}

Keywords: HIV test, Number of antenatal care, Stigmatization

\begin{abstract}
ABSTRAK
HIV AIDS merupakan suatu ancaman global di seluruh dunia serta memberikan dampak yang merugikan di semua sektor. Jumlah penderita HIV AIDS mengalami peningkatan baik pada laki-laki ataupun perempuan. Pada perempuan yang sedang hamil HIV bukan hanya menjadi ancaman bagi ibu namun juga bagi bayi, sehingga untuk mencegah adanya penularan dan kompliksi selama kehamilan harus dilakukan upaya skrining melalui tes HIV. Tujuan dari penelitian ini yaitu menganalisis hubungan jumlah kunjungan ANC dan stigmatisasi terhadap keikutsertaan ibu hamil dalam tes HIV setelah konseling oleh petugas kesehatan di Wilayah kerja puskesmas Turi Lamongan. Metode penelitian menggunakan rancangan cross sectional study. Populasi pada penelitian ini sebanyak 80 ibu hamil. Teknik sampling menggunakan simple random sampling, sehingga sampel penelitian diperoleh sejumlah 42 responden. Pengumpulan data menggunakan kuesioner dengan bantuan wawancara. Data dianalisis menggunakan tabel distribusi frekuensi dan uji chi square dengan tingkat kemaknaan $5 \%(\mathrm{p}=0,05)$. Sesuai hasil penelitian dari 42 ibu hamil yang melakukan kunjungan ANC $>4 \mathrm{kali} 100 \%$ tidak mengikuti tes HIV, pada kunjungan 2-4 kali sebanyak 16 orang (64\%) mengikuti tes HIV, pada kunjungan 1 kali
\end{abstract}


sebanyak 1 orang yang mengikuti tes HIV. Dari ibu yang tidak memiliki stigma didapatkan 100\% mengikuti tes HIV. Hasil uji statistik menunjukkan ada hubungan signifikan jumlah kunjungan ANC $(p=0,000)$ dengan keikutsertaan ibu hamil dalam tes HIV dan ada hubungan signifikan stigmastisasi $(p=0,000)$ dengan keikutsertaan ibu hamil dalam tes HIV. Peningkatan pemberian informasi dan edukasi perlu dilakukan pada ibu melalui promosi kesehatan seputar pentingnya tes HIV dan pentingnya kunjungan pemeriksaan kehamilan ulang pada tenaga kesehatan.

Kata kunci: jumlah kunjungan pemeriksaan kehamilan, stigmatisasi, tes HIV

\section{PENDAHULUAN}

HIV AIDS (Human Immunodeficiency Virus/Acquired Immune Deficiency Syndrome) menjadi masalah dan merupakan suatu penyakit yang memberikan ancaman global di seluruh dunia serta memberikan dampak yang merugikan di semua sektor. Menurut WHO (2006) HIV AIDS menjadi penyebab kematian peringkat atas dengan mortalitas dan morbiditas yang tinggi, untuk mengatasinya juga membutuhkan diagnosis dan terapi yang cukup lama.

Berdasarkan laporan global dari UNAIDS (United Nation Acquired Immune Deficiency Syndrome) pada tahun 2013 terdapat 35 juta orang hidup dengan HIV yang meliputi 16 juta dengan jenis kelamin perempuan dan 3,2 juta anak berusia $<15$ tahun (Kemenkes RI, 2014). Jumlah infeksi HIV baru pada tahun 2013 sebesar 2,1 juta yang terdiri dari 1,9 juta dewasa dan 240.000 anak berusia $<15$ tahun. AIDS juga menyebabkan kematian yaitu sebanyak 1,5 juta yang terdiri dari 1,3 juta dewasa dan 190.000 anak berusia $<15$ tahun (Kemenkes RI, 2014). Pada saat ini di Indonesia penyakit HIV AIDS telah menyebar di 386 kabupaten/ kota di seluruh provinsi di Indonesia, adapun jumlah kasus yang terdapat di Indonesia mulai tahun 1987 sampai dengan bulan September 2014 adalah sejumlah 150.296 orang.

Menurut Widoyono (2011) infeksi HIV memberikan peluang pada kelompokkelompok tertentu, yaitu pada kelompok risiko tinggi antara lain yaitu: individu yang suka berganti pasangan seksual, pengguna jarum suntik secara bersama-sama dimana jarum tersebut telah terkontaminasi dengan virus HIV, bayi yang dikandung oleh ibu yang telah terinfeksi HIV serta seseorang yang sedang memerlukan transfusi darah secara teratur misalnya pada penderita thalasemia dan haemopilia dimana pada pendonor tidak dilakukan skrining. Infeksi HIV AIDS bisa menular pada setiap orang, maka dari itu infeksi HIV AIDS memberikan peluang pada setiap orang untuk mengalaminya, termasuk juga seorang ibu hamil. Ibu hamil terinfeksi virus HIV kemungkinan besar diperoleh dari pasangan seksualnya. Pada infeksi HIV bisa ditularkan pada bayi selama masa kehamilan, persalinan dan menyusui. Menurut WHO (2013) lebih dari 90\% kasus anak dengan HIV memperoleh infeksi melalui penularan dari ibu ke anak (motherto-child transmission/MTCT).

Jumlah penderita HIV dilaporkan meningkat dan selalu mengalami kenaikan sejak tahun 1987 sampai September 2014, hal tersebut berdasarkan data Kemenkes RI (2014). Pola penularan yang terjadi sepertinya hampir sama yaitu terjadi peningkatan paling banyak pada kelompok laki-laki dibandingkan dengan kelompok perempuan. Menurut Kemenkes RI (2013) peningkatan tersebut juga memberikan efek pada peningkatan jumlah perempuan yang terinfeksi HIV jika menjadi pasangan seksualnya. Berdasarkan data Kemenkes RI (2012) menunjukkan dari 21.103 ibu hamil, $534(2,5 \%)$ positif telah terinfeksi HIV.

Menurut Manuaba (2007) pada dasarnya infeksi HIV bukan hanya menjadi ancaman bagi keselamatan ibu, namun juga merupakan ancaman bagi bayi yang dikandungnya karena penularan yang berasal dari ibu ke bayi. Ancaman yang bisa terjadi 
pada ibu antara lain, pneumonia bakteri, ISK (Infeksi Saluran Kemih), toksoplasmosis, PMS (Penyakit Menular Seksual), abses paska bedah dan endometritis pascapartum, sedangkan pada bayi infeksi HIV dapat menyebabkan rupture membran premature, kematian janin, kelahiran premature dan berat bayi lahir rendah. Penularan dan komplikasi harus dicegah dan diatasi, salah satu upaya yang bisa dilakukan yaitu upaya skrining sedini mungkin pada ibu hamil melalui tes HIV.

Di Indonesia telah dilakukan program Pencegahan Penularan HIV dari Ibu ke Anak (PPIA) atau Prevention of Mother to Child HIV Transmission (PMTCT), upaya tersebut bertujuan untuk mencegah penularan HIV dari ibu ke bayi serta mengurangi dampak epidemi HIV terhadap ibu dan bayi. Konseling dan Tes HIV mencegah penularan dari ibu ke akan jika seorang ibu tersebut telah terinfeksi HIV, hal tersebut sesuai dengan rekomendasi dari WHO bahwa pada dasarnya semua ibu hamil harus ditawarkan untuk tes HIV. Tes HIV ini dilakukan dengan tujuan dapat mengetahui lebih cepat adanya infeksi HIV pada ibu hamil sehingga dapat segera diberikan terapi, persiapan persalinan yang aman dan pemberian profilaksis pada bayi yang dikandung sehingga bayi dapat terhindar dari infeksi HIV (WHO, 2013).

Data Kemenkes (2013) menunjukkan apabila tanpa upaya khusus, maka diperkirakan pada akhir tahun 2016 akan terjadi penularan HIV secara kumulatif pada lebih dari 26.977 anak yang dilahirkan dari ibu yang telah terinfeksi HIV. Tes HIV ini bisa didapatkan ibu secara sukarela atau pun atas inisiasi petugas kesehatan pada tempat pelayanan kesehatan ataupun ketika ibu berkunjung untuk melakukan kunjungan pemeriksaan kehamilan. Hal tersebut sesuai dengan program PPIA atau sebagai upaya integrasi dengan pelayanan Kesehatan Ibu dan Anak (KIA) (Kemenkes RI, 2013). Sesuai dengan Peraturan Menteri Kesehatan no. 21/2013 bahwa pemeriksaan diagnosis HIV dilakukan untuk mencegah sedini mungkin terjadinya penularan atau peningkatan kejadian infeksi HIV.

Pada kenyataannya upaya tersebut belum bisa berjalan secara optimal. Di negara maju risiko penularan dari ibu ke anak dapat ditekan hingga kurang dari $2 \%$ karena layanan PPIA tersedia dan dilaksanakan secara optimal. Hal tersebut tidak terjadi di negara berkembang ataupun miskin. minimnya akses terhadap pelayanan, menyebabkan risiko penularan bisa berkisar antara 24\%-45\% (Kemenkes, 2013). Beberapa penyebab kurang optimalnya program tersebut yaitu adanya pemikiran masyarakat yang masih menganggap bahwa HIV AIDS merupakan penyakit yang harus dijauhi serta sangat tabu untuk dibicarakan. Adanya anggapan bahwa individu yang terinfeksi HIV harus dikucilkan karena sangat rentan untuk menularkan HIV. Berdasarkan data Riskesdas (2013) di propinsi Jawa Timur sendiri, tepatnya di wilayah Kabupaten Lamongan menduduki peringkat ke 10 dengan jumlah kasus HIV AIDS sejumlah 407 kasus. Secara realita, Kabupaten Lamongan merupakan kota yang tidak terlalu besar, hal tersebut jauh dari kondisi kota besar lainnya yang sangat berpotensi terjadi peningkatan kasus HIV AIDS. Adanya sejumlah kasus yang terjadi memang tidak lepas dari adanya faktor mobilisasi penduduk, dimana banyak didirikan pabrik baru yang tentu saja menarik tenaga kerja baru. Tenaga kerja tersebut tidak hanya berasal dari dalam daerah namun juga luar daerah. Kabupaten Lamongan juga merupakan jalur di wilayah utara dari pulau Jawa. Hal tersebut juga bisa menyebabkan mobilisasi sopir-sopir truk luar kota yang bisa kapanpun waktunya untuk istirahat di Kabupaten Lamongan. Di Kabupaten Lamongan sendiri tidak semua Puskesmas memiliki fasilitas layanan Antenatal Care Terpadu (ANC Terpadu), dalam hal ini sangat dimungkinkan bahwa masih banyak ibu hamil yang belum mendapatkan layanan pemeriksaan HIV sehingga kemungkinan adanaya ibu hamil yanga terinfeksi HIV juga tidak diketahui. Berdasarkan data dari 
Puskesmas Turi yang telah memiliki fasilitas ANC Terpadu, pada tahun 2015 dari 793 ibu hamil, hanya $303(38,2 \%)$ orang ibu hamil yang mengikuti tes HIV.

Hasil wawancara pada 10 orang ibu hamil didapatkan hasil 4 (40\%) orang bersedia untuk tes HIV dengan alasan adanya anjuran petugas kesehatan, ingin mengetahui status HIV-nya, mencoba karena gratis. Selain itu ada juga ibu hamil yang tidak mengikuti tes atau menolak penawaran petugas dikarenakan takut jika mengetahui terinfeksi HIV, takut dengan pandangan orang sekitar karena penyakit HIV/AIDS merupakan suatu aib serta tidak diperbolehkan keluarga karena merasa sehat-sehat saja, selain itu ibu hamil juga mengatakan bahwa mereka baru saja melakukan kunjungan yang pertama kali sehingga belum tertarik untuk mengikuti. Menurut Kemenkes RI (2010) setiap ibu hamil wajib melakukan kunjungan kehamilan pertama kali di pusat pelayanan kesehatan dasar untuk memperoleh pelayanan secara terpadu dan komprehensif.

Menurut Paoli dkk. (2004) mengatakan bahwa perilaku ibu hamil untuk mengikuti tes HIV tidak hanya berhubungan dengan pendidikan, namun berhubungan dengan stigma di masyarakat, persepsi kerentanan, persepsi keparahan, persepsi halangan dan adanya keterlibatan dukungan dari keluarga baik suami maupun keluarga lain.

Di Lamongan sendiri belum pernah dilakukan penelitian sejenis ini sehingga perlu diteliti mendalam berbagai faktor yang mempengaruhi keikutsertaan pemeriksaan HIV pada ibu hamil setelah mendapatkan konseling sebagai upaya PPIA agar Kabupaten Lamongan secara berangsur bisa menurunkan jumlah kasus HIV AIDS.

\section{METODE PENELITIAN}

Jenis penelitian yang digunakan yaitu observasional analitik dengan rancang bangunnya menggunakan desain cross sectional study untuk melihat faktor yang berhubungan terhadap keikutsertaan ibu hamil dalam tes HIV.
Penelitian dilaksanakan di wilayah kerja Puskesmas Turi Kabupaten Lamongan. Waktu penelitian yaitu pada bulan Maret 2016-Juni 2016. Pengambilan data awal dilakukan pada bulan Maret 2016 kemudian penelitian secara keseluruhan dilaksanakan pada awal bulan Mei sampai awal Juni 2016.

Populasi penelitian ini adalah semua ibu hamil yang berkunjung ke Puskesmas Turi dalam 1 bulan untuk melakukan pemeriksaan kehamilan dan belum melakukan tes HIV saat datang ke Puskesmas Turi, yaitu sebanyak 80 ibu hamil.

Teknik sampling yang digunakan yaitu probability sampling dengan simple random sampling. Peneliti berasumsi bahwa setiap ibu hamil yang datang mendapatkan konseling tentang HIV sekaligus tentang tes HIV yang ditawarkan sebelumnya oleh konselor. Penawaran tersebut wajib dilakukan di seluruh Puskesmas yang memiliki fasilitas ANC Terpadu. Perhitungan tersebut didapatkan sampel penelitian sejumlah 42 responden.

Dalam penelitian ini variabel bebas adalah jumlah kunjungan ANC dan stigmatisasi, sedangkan variable terikat adalah keikutsertaan ibu hamil dalam tes HIV setelah konseling petugas kesehatan. Pengumpulan data berupa data primer yang diperoleh melalui wawancara dengan bantuan instrumen kuesioner.

Analisis data menggunakan table distribusi frekuensi dan uji chi square. Jika $p$ value $<0,05$, artinya ada hubungan antara jumlah kunjungan ANC dengan keikutsertaan ibu hamil dalam tes HIV setelah konseling oleh petugas kesehatan dan ada hubungan stigmastisasi dengan keikutsertaan ibu hamil dalam tes HIV setelah konseling oleh petugas kesehatan. Pada hasil uji chi square yang memiliki nilai $p$ value $<0,05$ dilakukan perhitungan prevalence ratio (PR) untuk mencari besar risiko.

\section{HASIL}

Berdasarkan hasil penelitian distribusi frekuensi untuk jumlah kunjungan 
Tabel 1. Distribusi Frekuensi Berdasarkan Jumlah Kunjungan ANC dan Stigmatisasi dengan keikutsertaan ibu hamil dalam tes HIV setelah konseling oleh petugas kesehatan Tahun 2016

\begin{tabular}{lcc}
\hline Karakteristik ibu hamil & Jumlah & $\begin{array}{c}\text { Persentase } \\
(\%)\end{array}$ \\
\hline Jumlah Kunjungan & & \\
$\quad$ 1 kali & 15 & 35,71 \\
4-4 kali & 25 & 59,52 \\
$\quad$ 4 kali & 2 & 4,76 \\
Stigmatisasi & & \\
$\quad$ Ada stigma & 28 & 66,66 \\
$\quad$ Tidak ada stigma & 14 & 33,33 \\
\end{tabular}

pemeriksaan kehamilan terdiri dari ibu hamil yang memeriksakan diri sebanyak 1 kali, 2-4 kali (kunjungan ke 2, 3 dan 4) dan $>4$ kali (kunjungan ke 5), pada variabel stigmatisasi terdiri dari ibu yang memiliki stigma dan tidak memiliki stigma. Data selengkapnya akan disajikan dalam tabel berikut.

Pada tabel 1 jumlah kunjungan ANC sebagian besar ibu hamil yang berkunjung ke Puskesmas Turi melakukan kunjungan 2-4 kali yaitu 25 orang $(59,52 \%)$, pada kunjungan ANC 1 kali terdiri dari 15 orang $(35,71 \%)$ dan pada kunjungan $>4$ kali hanya terdiri dari 2 orang $(4,76 \%)$.

Pada variabel stigmatisasi diperoleh hasil sebagian besar sebanyak 28 orang (66,66\%) memiliki stigma terhadap HIV AIDS maupun tesnya.

Menurut hasil penelitian yang ditunjukkan tabel 1 melalui distribusi frekuensi, kemudian dilanjutkan dengan tabulasi silang pada kedua variabel penelitian yaitu jumlah kunjungan ANC dan stigmatisasi dengan keikutsertaan ibu hamil dalam tes HIV setelah konseling oleh petugas kesehatan di Puskesmas Turi Kabupaten Lamongan.

Dari tabel 2 didapatkan bahwa pada kunjungan kehamilan $>4$ kali sebanyak $(100 \%)$ tidak mengikuti tes HIV. Pada kunjungan ANC 2-4 kali proporsi yang ikut dalam tes HIV sebanyak 16 ibu hamil
Tabel 2. DistribusiFrekuensiBerdasarkan Jumlah Kunjungan ANC dan Stigmatisasi dengan keikutsertaan ibu hamil dalam tes HIV setelah konseling oleh petugas kesehatan Tahun 2016

\begin{tabular}{|c|c|c|c|c|c|c|}
\hline \multirow{3}{*}{ Faktor } & \multicolumn{4}{|c|}{ Keikutsertaan } & \multirow{2}{*}{\multicolumn{2}{|c|}{ Total }} \\
\hline & \multicolumn{2}{|c|}{ Ikut } & \multicolumn{2}{|c|}{ Tidak ikut } & & \\
\hline & $\mathbf{n}$ & (\%) & $\mathbf{N}$ & $(\%)$ & n & $(\%)$ \\
\hline \multirow{2}{*}{\multicolumn{7}{|c|}{$\begin{array}{l}\text { Jumlah } \\
\text { kunjungan }\end{array}$}} \\
\hline & & & & & & \\
\hline$>4$ kali & 0 & 0 & 2 & 100 & 2 & 100 \\
\hline 2-4 kali & 16 & 64 & 9 & 36 & 25 & 100 \\
\hline 1 kali & 1 & 6,66 & 14 & 93,3 & 15 & 100 \\
\hline \multicolumn{7}{|l|}{ Stigmatisasi } \\
\hline $\begin{array}{l}\text { Tidak ada } \\
\text { stigma }\end{array}$ & 14 & 100 & 0 & 0 & 14 & 100 \\
\hline Ada stigma & 3 & 10,71 & 25 & 89,2 & 28 & 100 \\
\hline
\end{tabular}

(64\% dan pada kunjungan ANC 1 kali proporsi yang ikut dalam tes HIV hanya 1 ibu hamil $(6,66 \%)$. Berdasarkan hasil uji statistik dengan menggunakan chi square menunjukkan bahwa $p$ value $(0.000)<$ $\alpha(0,05)$ yang berarti jumlah kunjungan ANC mempunyai hubungan signifikan dengan keikutsertaan ibu dalam tes HIV setelah konseling oleh petugas kesehatan di Puskesmas Turi Kabupaten Lamongan.

Dari tabel 2 didapatkan bahwa pada ibu hamil yang tidak memiliki stigma terhadap HIV semuanya memilih ikut tes HIV (100\%), pada ibu hamil yang memiliki stigma terhadap HIV proporsi yang ikut tes HIV sebanyak $3 \mathrm{ibu}$ hamil (10,71\%). Hasil uji statistik menunjukkan bahwa $p$ value $(0,000)<\alpha(0,05)$ yang berarti stigmatisasi mempunyai hubungan signifikan dengan keikutsertaan ibu hamil dalam tes HIV setelah konseling oleh petugas kesehatan di Puskesmas Turi Kabupaten Lamongan.

Setelah dilakukan uji statistik $C h i$ Square, dilakukan perhitungan untuk nilai prevalence ratio $(\mathrm{PR})$ untuk menilai besar risiko. Pada variabel jumlah kunjungan ANC untuk kunjungan $>4$ kali nilai $\mathrm{PR}=0$, artinya pada kunjungan $\mathrm{ANC}>4$ kali bukan faktor risiko keikutsertaan ibu hamil 
dalam tes HIV. PR untuk kunjungan 2-4 kali yaitu sebesar 9,7 artinya ibu hamil yang melakukan kunjungan ANC 2-4 kali memiliki besar risiko sebanyak 9,7 untuk ikut tes HIV dibanding dengan ibu hamil yang melakukan kunjungan ANC 1 kali.

Nilai prevalence ratio untuk variabel stigmatisasi yaitu sebesar 9,09, yang artinya ibu hamil yang tidak memiliki stigma memiliki besar risiko 9,09 kali untuk ikut dalam tes HIV dibanding ibu hamil yang memiliki stigma.

\section{PEMBAHASAN \\ Jumlah Kunjungan ANC}

Hasil penelitian diperoleh bahwa pada ibu yang melakukan kunjungan $>4$ kali tidak ada yang mengikuti tes HIV. Pada kunjungan kehamilan 2-4 kali lebih dari separuh mengikuti tes HIV dan pada kunjungan 1 kali hanya sebagian kecil yang mengikuti tes HIV. Hasil uji statistik menyatakan bahwa jumlah kunjungan pemeriksaan kehamilan berhubungan secara signifikan dengan keikutsertaan ibu hamil dalam tes HIV. Semakin banyak kunjungan untuk pemeriksaan kehamilan yang dilakukan oleh ibu hamil semakin banyak pula informasi yang didapat oleh ibu hamil di tiap-tiap kunjungannya termasuk informasi tentang HIV/AIDS. Menurut Varney (2010) perempuan usia reproduktif yang rajin untuk melakukan ante natal care lebih mudah untuk mendapatkan informasi seputar kesehatan reproduksi, kehamilan, persalinan dan nifas serta perawatan bayi batu lahir. Informasi tersebut mencakup upaya-upaya deteksi dini terhadap komplikasi yang bisa terjadi di setiap fasenya.

Prevalensi Ratio untuk kunjungan $>$ 4 kali bukan faktor risiko dari keikutsertaan ibu dalam tes HIV. Berdasarkan hasil yang diperoleh meskipun jumlah kunjungan ibu hamil $>4$ kali namun 2 ibu hamil tersebut $(100 \%)$ memilih untuk tidak ikut dalam tes HIV, hal tersebut teridentifikasi dikarenakan kedua ibu hamil memiliki pengetahuan yang kurang tentang HIV AIDS termasuk tentang tes HIV, sedangkan pada ibu hamil yang melakukan kunjungan pemeriksaan kehamilan 2-4 kali memiliki risiko untuk mengikuti tes HIV lebih besar dibandingkan dengan ibu hamil yang melakukan kunjungan pemeriksaan kehamilan 1 kali. Hal tersebut dapat disimpulkan bahwa semakin sering seorang ibu hamil melakukan kunjungan untuk memeriksakan kehamilannya maka semakin besar peluang untuk mengikuti tes HIV. Hal ini dikarenakan semakin sering ibu kontak dengan tenaga kesehatan semakin besar kemungkinan mendapat informasi yang lebih baik terkait kesehatan ibu dan anak (Depkes RI, 2006). Menurut Manuaba (2007) dalam pemeriksaan kehamilan upaya yang penting dilakukan selain memberikan pelayanan pemeriksaan dan perawatan yang diperlukan, penting juga untuk dilakukan pemberian edukasi kepada ibu hamil. Hal tersebut dikarenakan masa kehamilan merupakan masa dimana seorang wanita mempunyai kesempatan untuk mencetak generasi yang sehat. Anak yang dilahirkan sehat, secara fisik dan psikis tentu saja berawal dari kesehatan seorang ibu. Ibu yang sehat lebih besar peluang untuk melahirkan bayi yang sehat pula (Wiknjosastro, 2008). Edukasi yang diberikan pada perempuan yang hamil mengikuti perkembangan tahapan kehamilan (Afiyanti, 2004). Ibu hamil harus paham pada setiap perubahan yang terjadi selama kehamilannya hal tersebut dilakukan agar ibu mengetahui secara bertahap persiapan yang dilakukan termasuk ibu hamil akan belajar untuk bisa mendeteksi adanya kelainan yang bisa terjadi saat hamil (Fernandez, 2000). Ibu hamil harus melakukan kontak dengan tenaga kesehatan untuk mendapatkan pelayanan terpadu dan komprehensif sesuai standar (Kemenkes Ri, 2010)

Menurut penelitian Worku (2005) Ibu yang melakukan setidaknya dua kali kunjungan antenatal care lebih mungkin untuk menerima tes HIV dibandingkan dengan ibu yang hadir kurang dari dua kunjungan antenatal. Demikian halnya 
menurut penelitian oleh Malaju dan Alene (2012) bahwa ibu yang menerima dua atau lebih antenatal care lebih mungkin untuk menerima tes HIV daripada mereka yang menghadiri pelayanan antenatal hanya sekali, namun dari hasil penelitian didapatkan masih adanya ibu hamil yang tidak mengikuti tes HIV meskipun sudah melakukan kunjungan $>4$ kali. Ibu hamil yang tidak mengikuti tes HIV tersebut memiliki pengetahuan kurang, sehingga bisa disimpulkan bahwa keikutsertaan ibu hamil dalam tes HIV tidak hanya dipengaruhi oleh jumlah kunjungan pemeriksaan kehamilan tetapi juga bisa dipengaruhi oleh faktor yang lain.

\section{Stigmatisasi}

Dari hasil penelitian menunjukkan bahwa ibu hamil yang tidak memiliki stigma terhadap HIV/AIDS semua ikut dalam tes HIV. Namun dari ibu hamil yang memiliki stigma terhadap HIV/AIDS tidak semua memilih untuk tidak mengikuti tes HIV, ada beberapa ibu hamil yang tetap memilih untuk tes HIV. Hasil uji statistik menunjukkan bahwa stigmastisasi mempunyai hubungan signifikan dengan keikutsertaan bu hamil dalam tes HIV.

Menurut UNAIDS (2007), stigma dan diskriminasi terhadap penderita HIV AIDS akan berdampak terhadap upaya pencegahan HIV seperti orang akan enggan untuk melakukan tes HIV karena takut akan mendapatkan stigma dan diskriminasi apabila hasil tesnya positif. Hal tersebut juga akan terjadi pada ibu hamil yang memiliki stigma akan cenderung untuk tidak mengikuti tes HIV.

Berdasarkan hasil penelitian ibu yang memiliki stigma cenderung tidak mengikuti tes HIV dikarenakan pandangan yang sudah negatif terhadap HIV/AIDS maupun terhadap penderitanya. Menurut Sarwono (2007) cara pandang seseorang terhadap sesuatu akan mempengaruhi setiap tindakan yang dilakukan. Seseorang yang memiliki penilaian kurang baik terhadap suatu hal, maka akan ada kecenderungan untuk menarik diri dari kondisi tersebut. Begitupun yang terjadi pada ibu hamil yang memiliki stigma terhadap HIV AIDS termasuk pada tes HIV, ibu hamil yang sudah memiliki stigma akan cenderung untuk merasakan kuatir terhadap segala sesuatu yang berhubungan dengan HIV dikarenakan ada anggapan bahwa HIV AIDS merupakan suatu penyakit yang luar biasa dan belum ditemukan obat sampai saat ini. Menurut Widoyono (2011) penyakit HIV perlu diwaspadai, namun penyakit tersebut memiliki cara penularan yang tidak mudah dan membutuhkan tahapan yang panjang. Menurut Kemenkes RI (2012) cara penularan HIV melalui hubungan seksual dengan berganti-ganti pasangan, adanya pajanan oleh darah dan adanya penularan dari ibu ke anak, sedangkan kelompok risiko tinggi untuk bisa tertular HIV yaitu individu yang berganti-ganti pasangan, penjaja seksual dan pelanggannya, pengguna jarum suntik secara bersama-sama (bergantian), bayi yang dikandung ibu yang terinfeksi HIV dan orang yang memerlukan transfusi darah teratur bila darah yang didonorkan tidak diskrining. Halhal semacam itu seharusnya dapat diketahui oleh masyarakat luas, sehingga stigma yang selama ini cenderung mengucilkan penderita HIV berangsur-angsur bisa dihilangkan. Menurut Komisi Penanggulangan AIDS Nasional (2010) penderita HIV sama dengan masyarakat pada umumnya, mereka memilki hak yang sama, hak untuk merdeka dan tidak ditindas sehingga adanya stigma dan persepsi yang selama ini terjadi di masyarakat sudah selayaknya untuk dihilangkan.

Menurut Reni (2015) stigma tentang HIV mempengaruhi seorang perempuan untuk menerima upaya yang terkait dengan pemberantasan infeksi HIV. Hal tersebut terjadi karena dalam diri mereka sudah berkembang sejumlah informasi yang mengatakan bahwa HIV AIDS merupakan penyakit yang sangat memalukan dan tidak layak untuk dibicarakan di masyarakat luas. Ibu hamil yang mempunyai anggapan dan stigma bahwa HIV merupakan penyakit yang tidak layak diperbincangkan lebih 
besar kemungkinan untuk merasa takut dalam menjalani tes HIV, kekuatiran tersebut antara lain takut dibicarakan tetangga dan takut hasilnya positif (Legiati, 2012).

Penelitian menyatakan bahwa pada ibu yang tidak memiliki stigma, mempunyai risiko lebih besar untuk mengikuti tes HIV dibandingkan dengan ibu yang memiliki stigma terhadap HIV/AIDS dan hal yang terkait HIV termasuk juga tes HIV. Hasil penelitian diperoleh rincian data, bahwa pada ibu yang memiliki stigma terhadap HIV termasuk tes HIV didapatkan bahwa seluruh ibu hamil mempunyai anggapan harus menjaga jarak dengan penderita HIV, ibu hamil yang memiliki stigma terhadap HIV mempunyai pemikiran bahwa ibu hamil dengan HIV positif tidak boleh mengikuti posyandu di tempat yang sama termasuk kegiatan perawatan kehamilan secara teratur dan adanya anggapan bahwa berbicara dengan penderita HIV akan dapat tertular oleh penyakitnya. Adanya stigma seperti ini tentu saja semakin membuat ibu hamil yang memiliki risiko terinfeksi HIV akan menarik diri dari pergaulan di masyarakat. Hal tersebut menyebabkan tidak terdeteksinya secara dini adanya komplikasi dan kelainan selama masa kehamilan. Adanya stigma ini akan mendukung bertambahnya kasus HIV AIDS yang tidak terdeteksi, dikarenakan masyarakat menutup diri (Kemenkes RI, 2010). Stigma berasal dari pengetahuan yang kemudian membentuk suatu persepsi.

Menurut Karen (2008) dalam teori Health Belief Model dinyatakan bahwa pengetahuan membentuk beberapa persepsi dalam proses pencegahan terhadap suatu penyakit. Persepsi membentuk stigma terhadap sesuatu. Penelitian oleh Worku (2005) keikutsertaan dalam tes HIV juga dipengaruhi oleh faktor yang lain misalnya pendidikan dan pengetahuan tentang berbagai aspek HIV/AIDS merupakan faktor yang ditemukan oleh peneliti bisa memainkan peran dalam keputusan untuk tes HIV. Hal tersebut sesuai dengan penelitian Fanta (2010) yang menyatakan bahwa keputusan untuk mengikuti tes HIV dipengaruhi oleh banyak faktor yang lain.

\section{SIMPULAN}

Puskesmas Turi Kabupaten Lamongan merupakan salah satu Puskesmas yang mempunyai fasilitas ANC yang di dalamnya ada fasilitas tes HIV. Dari hasil penelitian didapatkan bahwa jumlah kunjungan pemeriksaan kehamilan dan stigmatisasi memiliki hubungan dengan keikutsertaan ibu hamil dalam tes HIV, dimana semakin banyak jumlah kunjungan pemeriksaan kehamilan maka ibu hamil cenderung untuk mengikuti tes HIV, namun bisa juga jumlah kunjungan pemeriksaan kehamilan tidak hanya dipengaruhi oleh faktor jumlah kunjungan pemeriksaan kehamilan namun juga faktor-faktor yang lain. Begitupun dengan stigmatisasi, ibu yang tidak memiliki stigma terhadap penyakit HIV dan tes HIV maka akan cenderung untuk mengikuti tes HIV.

Petugas kesehatan agar memberikan informasi yang selengkap-lengkapnya tentang prosedur tes, informasi tentang penularan HIV dari ibu ke bayi dan upaya untuk menurunkan risiko penularan tersebut di wilayah kerja Puskesmas Turi Kabupaten Lamongan. Hal ini dilakukan dalam rangka untuk meningkatkan pengetahuan ibu hamil, memperbaiki persepsi yang kurang tepat terhadap HIV dan tes HIV sehingga stigma yang ada di masyarakat selama ini bisa berangsur dihilangkan.

Meningkatkan pemberian edukasi melalui promosi kesehatan tentang pada ibu hamil di setiap kunjungan kehamilan (misalnya di posyandu, di kelas ibu hamil, pemeriksaan kehamilan di semua tempat pelayanan kesehatan ataupun pada setiap wanita usia reproduktif di wilayah kerja Puskesmas Turi Kabupaten Lamongan tentang pentingnya pemeriksaan kehamilan ulang dan informasi terkait hubungan HIV AIDS dengan kehamilan.

Peningkatan peran Bidan maupun Dokter Praktek Swasta untuk melaksanakan 
program PPIA sampai bisa menjangkau semua wilayah khususnya wilayah yang jauh dari pusat pelayanan kesehatan. Hal tersebut dilakukan dalam rangka meningkatkan pengetahuan dan pemahaman masyarakat, khususnya ibu hamil termasuk di dalamnya yaitu pada keluarga terkait informasi tentang HIV AIDS dan pentingnya tes HIV

\section{DAFTAR PUSTAKA}

Afiyanti, Y. 2004. Studi fenomenologi tentang pengalaman wanita di daerah pedesaan dalam menjalani masa kehamilan pertama. Jurnal Keperawatan Indonesia

Badan Penelitian dan Pengembangan Kementerian Kesehatan RI. (2013). Riset Kesehatan dasar 2013. Jakarta: Kemenkes RI

Departemen Kesehatan RI. 2006. Pedoman pelayanan Konseling dan Testing HIV/ AIDS Secara Sukarela (Vouluntary Counselling and Testin) Jakarta :Depkes RI

Dinkes Jatim, 2012, Profil Kesehatan Provinsi Jawa Timur Tahun 2012, Surabaya: Dinkes Jatim

Fanta, W. dan Worku, A. 2012. Determinants for refusal of HIV testing among women attending for antenatal care in Gambella Region, Ethiopia, (Reproductive Health, 9:8) Available from : healthjournal.com/ content/9/1/8 (Accessed 2016, January 03).

Fernandez, M.I., Wilson, T.E., Ethier, K.A., Walter, E.B., Gay, C.L., Moore, J. (2000). Acceptance of HIV Testing During Prenatal Care", (Public Health Reports September-October 2000, 460 Volume 115), Available From : http:// www.ncbi.nlm.nih.gov/pmc/articles/ PMC1308602/pdf/pubhealthrep000200066.pdf (Diakses: 03 Januari 2016)

Karen Glanz at al, 2008, Health Behavior and Health Education (Theory, Research and Practice), San Francisco: Jossey-Bass

Kementerian Kesehatan RI, 2010, Pedoman Pelayanan Antenatal Terpadu, Jakarta: Direktur Jenderal Bina Kesehatan Masyarakat
Kementerian Kesehatan RI. 2012. Pedoman Nasional Pencegahan Penularan HIV Dari Ibu ke Anak (PPIA), Jakarta: Kementerian Kesehatan RI

Kementerian KesehatanRI. 2013. Pedoman Nasional Tes dan Konseling HIV dan AIDS, Jakarta: Kementerian Kesehatan RI

Kementerian Kesehatan RI. 2013. Permenkes RI Nomor 5 Tahun 2013 (Pedoman PPIA)

Kementerian Kesehatan RI. 2013. Permenkes RINomor 21 Tahun 2013 (Penanggulangan HIV AIDS)

Komisi Penanggulangan AIDS Nasional, 2010. Strategi dan Rencana Aksi Nasional Penanggulangan HIV/AIDS 2010-2014. Jakarta: Kementerian Koordinator Bidang Kesejahteraan Rakyat RI

Malaju,M.T.danAlene, G.D.2012.Assessment of utilization of providerinitiated HIV testing and counseling as an intervention for prevention of mother to child transmission of HIV and associated factors among pregnant women in Gondartown, North West Ethiopia, (BMC Public Health. 2012;12:226)Availablefrom:http:// www.ncbi.n1m.nih.gov/p m c/ articles/PMC3350437/?tool=pmcent ez\&report=abstract (Diakses: 03 Januari 2016)

Manuaba, (2007). Pengantar Kuliah Obstretri. Jakarta: EGC

Reni. 2015. Hubungan Stigma HIV/AIDS pada Ibu Rumah Tangga dengan Minat Melakukan VCT di Kelurahan Kricak Tegalrejo. Jurnal Ilmiah (Diakses 03 Januari 2016)

Paoli, De M.M., Manongi, R., Klepp, K.I. 2004. Factors influencing acceptability of Voluntary Counselling and HIV-testing Among Pregnant Women in Northern Tanzania (AIDS CARE (May 2004), Vol. 16, No. 4, pp. 411_/425) Available from : http://www.tandfonline.com/doi/abs/10.1 080/09540120410001683358\#.Uuxp_T1 _t1g (Diakses: 03 januri 2016) 
PS, T.Legiati., Shaluhiyah, Z., Suryoputro, A. 2012. Prilaku Ibu Hamil untuk Tes HIV di Kelurahan bandarharjo dan Tanjung Mas Kota Semarang, Jurnal PromosiKesehatan Indonesia Vol, 7/No.2/ Agustus 2012 Available from:ejournal. undip.ac.id/index.php/jpki/article/ download/5560/4942 (Diakses: 03 Januari 2016).

Sari, Ponco Indah Arista. 2016. Faktor yang Mempengaruhi Keikutsertaan Ibu Hamil Dalam Tes HIV (Human Immunodeficiency Virus) Setelah Mendapat Konseling Oleh Petugas Kesehatan. Tesis.Fakultas Kesehatan Masyarakat Universitas Airlangga Surabaya.

Sarwono, S., (2007) Sosiologi Kesehatan. Gajah Mada University Press. Yogyakarta
UNAIDS, 2007. Reducing HIV Stigma and Discrimination: a critical part of national AIDS programmes A resource for national stakeholders in the HIV response. Diakses pada tanggal 03 Januari 2016; http://data. unaids.org/pub/Report/2008/JC1521 stigmatisation_en.pdf

UNAIDS, 2013, Global Report (UNAIDS report on the global AIDS Epidemic)

Varney. (2010). Buku Saku Kebidanan. Jakarta: EGC

Widoyono, Penyakit Tropis (Epidemiologi, Penularan, Pencegahan dan Pemberantasannya), 2011, Semarang: Erlangga

Worku, G. 2005. "Factors Determining Acceptance of Vouluntary HIV Testing Among Pregnant Women Attending Antenatal Clinic at Armed Force Hospitals in Addis Ababa (tesis). Addis Ab 